\title{
Front Matter: Volume 7007
}

, "Front Matter: Volume 7007," Proc. SPIE 7007, INDLAS 2007: Industrial Laser Applications, 700701 (29 April 2008); doi: 10.1117/12.802271

SPIE. Event: INDLAS 2007: Industrial Laser Applications, 2007, Bran, Romania 


\title{
PROCEEDINGS OF SPIE
}

\section{INDLAS 2007: Industrial Laser Applications}

\author{
Mircea Udrea \\ Editor

\section{3-25 May 2007 \\ Bran, Romania}

\section{Organised by}

National Institute for Laser, Plasma and Radiation Physics (Romania)

Romanian Academy (Romania)

SPIE Romania Chapter (Romania)

Romanian Physical Society (Romania)

The Romanian Territorial Committee of ICO (Romania)

National Institute of Research and Development for Optoelectronics (Romania)

University of Bucharest (Romania)

University Politehnica of Bucharest (Romania)

\section{Cosponsors}

Ministry of Education and Research (Romania)

Coherent, Inc. (USA)

Ekspla (Lithuania)

\section{Published by}

SPIE 
The papers included in this volume were part of the technical conference cited on the cover and title page. Papers were selected and subject to review by the editors and conference program committee. Some conference presentations may not be available for publication. The papers published in these proceedings reflect the work and thoughts of the authors and are published herein as submitted. The publisher is not responsible for the validity of the information or for any outcomes resulting from reliance thereon.

Please use the following format to cite material from this book:

Author(s), "Title of Paper," in INDLAS 2007: Industrial Laser Applications, edited by Mircea Udrea, Proceedings of SPIE Vol. 7007 (SPIE, Bellingham, WA, 2008) Article CID Number.

ISSN 0277-786X

ISBN 9780819472175

Published by

SPIE

P.O. Box 10, Bellingham, Washington 98227-0010 USA

Telephone +1 3606763290 (Pacific Time) · Fax +1 3606471445

SPIE.org

Copyright (C 2008, Society of Photo-Optical Instrumentation Engineers

Copying of material in this book for internal or personal use, or for the internal or personal use of specific clients, beyond the fair use provisions granted by the U.S. Copyright Law is authorized by SPIE subject to payment of copying fees. The Transactional Reporting Service base fee for this volume is $\$ 18.00$ per article (or portion thereof), which should be paid directly to the Copyright Clearance Center (CCC), 222 Rosewood Drive, Danvers, MA 01923. Payment may also be made electronically through CCC Online at copyright.com. Other copying for republication, resale, advertising or promotion, or any form of systematic or multiple reproduction of any material in this book is prohibited except with permission in writing from the publisher. The CCC fee code is $0277-786 \mathrm{X} / 08 / \$ 18.00$.

Printed in the United States of America.

Publication of record for individual papers is online in the SPIE Digital Library.

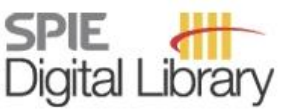

SPIEDigitallibrary.org

Paper Numbering: Proceedings of SPIE follow an e-First publication model, with papers published first online and then in print and on CD-ROM. Papers are published as they are submitted and meet publication criteria. A unique, consistent, permanent citation identifier (CID) number is assigned to each article at the time of the first publication. Utilization of CIDs allows articles to be fully citable as soon they are published online, and connects the same identifier to all online, print, and electronic versions of the publication. SPIE uses a six-digit CID article numbering system in which:

- The first four digits correspond to the SPIE volume number.

- The last two digits indicate publication order within the volume using a Base 36 numbering system employing both numerals and letters. These two-number sets start with 00, 01, 02, 03, 04, 05, $06,07,08,09,0 A, 0 B \ldots .0 Z$, followed by $10-1 Z, 20-2 Z$, etc.

The CID number appears on each page of the manuscript. The complete citation is used on the first page, and an abbreviated version on subsequent pages. Numbers in the index correspond to the last two digits of the six-digit CID number. 


\title{
Contents
}

\author{
vii Conference Committee \\ ix Introduction \\ xi Conference Sponsors and Organizers
}

\section{Industrial Laser Applications}

700702 Thin films technologies for utility devices [7007-01]

V. R. Medianu, C. Timus, National Institute for Lasers, Plasma, and Radiation Physics (Romania); L. Boroica, National Institute for Glass (Romania)

700703 Progress in developing nanophotonic integrated circuits [7007-02] T. Yatsui, Japan Science and Technology Agency (Japan); G.-C Yi, Pohang Univ. of Science and Technology (South Korea); M. Ohtsu, Japan Science and Technology Agency (Japan) and Univ. of Tokyo (Japan)

$700704 \quad$ New optics for industrial laser applications: VariSpot and VariFoc [7007-03] J. Serna, Univ. Complutense (Spain); G. Nemeş, Astigmat (USA)

700705 High-power continuous-wave Nd lasers under dioide pumping directly into the ${ }^{4} \mathbf{F}_{3 / 2}$ emitting level [7007-04]

N. Pavel, V. Lupei, National Institute of Laser, Plasma, and Radiation Physics (Romania)

$700706 \quad$ High power microchip solid state lasers [7007-05]

T. Dascalu, National Institute for Laser, Plasma, and Radiation Physics (Romania)

700707 Relativistic nonlinear Thomson scattering as a coherent source of high harmonic generation in interactions between very intense laser beams and plasmas [7007-06] A. Popa, National Institute of Laser, Plasma, and Radiation Physics (Romania)

700708 Optical differential evanescent investigation of nanometric dielectric materials morphology on waveguides [7007-07]

S. Popescu, Univ. Politehnica of Bucharest (Romania); N. Mirchin, I. Lapsker, Holon Institute of Technology (Israel); P. V. Notingher, Univ. Politehnica of Bucharest (Romania); I. Mihailescu, National Institute for Lasers (Romania); A. Peled, Holon Institute of Technology (Israel)

700709 Infrared and visible laser transitions in erbium-doped crystals [7007-08] S. Georgescu, O. Toma, National Institute for Laser, Plasma, and Radiation Physics (Romania)

7007 OA Application of whole blood image speckle analysis [7007-09]

D. Chicea, Univ. Lucian Blaga (Romania) 
7007 OB Development of a technological system for manufacturing diamond cutting disks by laser welding procedure [7007-10]

G. I. Gheorghe, P. Beca, C. Marinescu, National Institute of Research and Development for Precision Mechanics (Romania); I. Farcaş, C. Fenic, National Institute for Lasers, Plasma, and Radiation Physics (Romania)

7007 OC CHODIN: a computer code to simulate coherent light scattering dynamics on biological suspensions [7007-11]

D. Chicea, Univ. Lucian Blaga (Romania)

7007 OD Determination of the speed / bandwidth for fast photodetectors using picosecond lasers [7007-12]

E. Smeu, Univ. Politehnica of Bucharest (Romania)

7007 OE Thermal effects in the laser material marking and coloring with industrial applications [7007-13]

P. Sterian, E. Mocanu, Univ. Politehnica of Bucharest (Romania)

7007 OF The study of heating of transparent liquids for laser-liquids technologies [7007-14] M. Oane, G. Georgescu, F. Scarlat, R. Medianu, I. Mihailescu, National Institute for Laser, Plasma, and Radiation Physics (Romania); A. Peled, Holon Institute of Technology (Israel)

7007 OG Laboratory research for realizing incremental circular networks masks with laser micro-equipments [7007-15]

G. I. Gheorghe, National Institute of Research and Development for Precision Mechanics (Romania)

$7007 \mathrm{OH} \quad$ Automated generation of incremental linear networks masks by using photocomposition method with multiple microphotographical reductions using laser microsystems [7007-16] G. I. Gheorghe, National Institute of Research and Development in Precision Mechanics (Romania); O. Dontu, Univ. Politehnica of Bucharest (Romania)

7007 Ol Laser removal of thin layers for surface cleaning [7007-17] I. Apostol, D. Apostol, V. Damian, I. Iordache, F. Garoi, National Institute for Laser, Plasma, and Radiation Physics (Romania); E. Capello, Politechnic Univ. of Milan (Italy)

7007 OJ White light interferometry for vertical artifact calibration [7007-18] V. Damian, M. Bojan, A. Sima, National Institute for Laser, Plasma, and Radiation Physics (Romania); D. Cristea, A. Dinescu, R. Muller, National Institute for Microtechnologies (Romania)

7007 OK Laser applications in the field of MEMS [7007-19] G. M. Moagar-Poladian, IMT-Bucharest (Romania); Z. Illyefalvi-Vitez, B. Balogh, Univ. Politehnica of Bucharest (Romania); D. Ulieru, ROMES S.A. (Romania); A. Coraci, IMTBucharest (Romania)

7007 OL Sub-wavelength resolution laser lithography in the field of MEMS [7007-20] G. Moagar-Poladian, IMT-Bucharest (Romania) 
7007 OM Effects of the laser beam superficial heat treatment on the gas tungsten arc Ti-6al-4v welded metal microstructure [7007-21]

I. Voiculescu, O. Dontu, V. Geanta, Univ. Politehnica of Bucharest (Romania); S. Ganatsios, West-Macedonia Univ. (Greece)

7007 ON Laser heat treatment of welds for various stainless steels [7007-22]

O. Dontu, Univ. Politehnica of Bucharest (Romania); S. Ganatsios, West-Macedonia Univ. (Greece); N. Alexandrescu, C. Predescu, Univ. Politehnica of Bucharest (Romania)

$700700 \quad$ Micro-welding of stainless steel by pulsed Nd:YAG laser [7007-23]

O. Dontu, Univ. Politehnica of Bucharest (Romania); S. Ganatsios, Univ. of West Macedonia (Greece); D. Besnea, Univ. Politehnica of Bucharest (Romania); P. Beca, National Institute of Research and Development for Precision Mechanics (Romania)

7007 OP Continuous-wave diode end-pumped Nd:YAG and Nd:GdVO4 lasers passively Q-switched by $\mathrm{Cr}^{4+}:$ YAG saturable absorbers [7007-24]

C. Petre, N. Vasile, N. Pavel, T. Dascalu, National Institute for Laser, Plasma, and Radiation Physics (Romania)

7007 OQ Possibilities of increasing the pumping efficiency of solid active medium laser generators by optimizing the pumping cavity profile [7007-25]

O. Dontu, Univ. Politehnica of Bucharest (Romania); S. Ganatsios, Univ. of West Macedonia (Greece); N. Alexandrescu, Univ. Politehnica of Bucharest (Romania)

Author Index 
Downloaded From: https://www.spiedigitallibrary.org/conference-proceedings-of-spie on 26 Apr 2023

Terms of Use: https://www.spiedigitallibrary.org/terms-of-use 


\title{
Conference Committees
}

\author{
Conference Chair
}

Mircea Udrea National Institute for Lasers Plasma and Radiation Physics

(Romania)

Scientific Committee Coordinator

Constantin Grigoriu (Romania)

Scientific Committee
S. Bilikmen (Turkey)
D. Dascalu (Romania)
D. Dumitras (Romania)
F. Flory (France)
C. Fotakis (Greece)
V. I. Konov (Russia)
N. Kroo (Hungary)
Gh. Marian (Romania)
A. Peled (Israel)
P. Reinhard Germany
V. I. Vlad (Romania)

Programme Committee

D. Apostol (Romania)

A. Andriesh (Moldavia)

R. Bobulescu (Romania)

V. Ciupina (Romania)

B. Comanescu (Romania)

R. Dabu (Romania)

T. Dascalu (Romania)

M. Dinescu (Romania)

O. Dontu (Romania)

S. Georgescu (Romania)

I. Gruia (Romania)

A. Lupascu (Romania)

V. Lupei (Romania)

R. Medianu (Romania)

I. Mihailescu (Romania)

G. Moagar Poladian (Romania)

I. Morjan (Romania) 
T. Necsoiu (Romania)

G. Nemes (USA)

I. Nica (Moldavia)

Doina Nicolae (Romania)

A. Petris (Romania)

Angela Piegari (Italy)

N. Puscas (Romania)

Roxana Savastru (Romania)

D. Sporea (Romania)

G. Stanciu (Romania)

P. Sterian (Romania)

T. Tudor (Romania)

Organising Committee Coordinator

Petronela Doia (Romania)

Organising Committee

Tatiana Bazaru (Romania)

Mariana Buzatu (Romania)

Florenta Craciun (Romania)

loan Dancus (Romania)

S. Georgescu (Romania)

Sanda Olteanu (Romania)

C. Stan (Romania)

E. Smeu (Romania)

Treasurer

Alexandra Olteanu (Romania) 


\section{Introduction}

The international conference INDLAS 2007 held in Bran, Romania is the first edition of an annual series of conferences dedicated to laser applications. The topics of this conference reflect applications in material processing, optoelectronics, biology and medicine, and sensing and metrology. Our event expresses the more and more obvious role of lasers in the progress of modern society. Far from being only a scientific domain, the laser has become a familiar tool in many applications.

INDLAS offers an opportunity to share experiences, discuss the newest results, stimulate interdisciplinary research, and consider the realm of laser applications. Since Romania is a country under continuous and rapid development, a jump to the newest technologies, as laser is, even skipping some steps, seems to be attractive for different institutes and companies all over the world. Another stimulating factor is the participation of Romania in the frame of EU Research and Development programmes.

INDLAS 2007 benefited from the support of several national and international institutions. We thank and SPIE-RO (the Romanian Chapter), the Romanian Academy, the National Institute of Optoelectronics (INOE 2000), the University of Bucharest, and the University Politehnica of Bucharest. And special thanks to the National Institute of Laser, Plasma, and Radiation Physics (NILPRP).

Thanks are due to the co-sponsoring institutions: The Romanian Ministry of Education and Research, Coherent, Inc. (USA), and Ekslpa (Lithuania).

Scientific papers by authors from 7 different countries have been selected for presentation at INDLAS 2007, in plenary lectures, invited lectures, oral presentations, and posters. Some of these papers, reviewed by the international referee board, are published in this SPIE Proceedings volume. We express our gratitude to the referees, to the invited professors, and to the participants for their valuable work.

I would like to express my thanks to the members of the International Scientific Committee, Programme Committees and Organising Committees of INDLAS 2007 for their hard work. A special address and thanks are due to Dr. R. Medianu, the General Director of NILPRP, Dr. A. Petris, Ms. Petronela Doia, and Mrs. Mariana Buzatu, who were the key members of the Organizing Committees. We thank them for their efforts and support of this conference. We acknowledge Mrs. Doina Nicolae and Ms. Camelia Talianu for the design and updating the conference web site. The preparation of the conference programme and of this volume is largely due to the hard work of Ms. Petronela Doia, who deserves our gratitude and the appreciation of our community. 
I hope that the participants in INDLAS 2007 have enjoyed the scientific sessions, have reconnected with their friends, and have had the opportunity to start new scientific collaborations.

Since most of the participants have already expressed their wish to participate at INDLAS 2008, I consider our first attempt as a success to be continued in the years to come.

\section{Mircea Udrea}




\section{Organised by}

NILPRP—National Institute for Laser, Plasma, and Radiation Physics (Romania)

Romanian Academy - Division of Physics

SPIE Romania Chapter

Romanian Physical Society, Division of Optics and Quantum Electronics

Romanian Physical Society, Division of Optics and Quantum Electronics, The Romanian Territorial Committee of ICO

INOE 2000—National Institute of Research and Development for Optoelectronics (Romania)

University of Bucharest, Faculty of Physics (Romania)

University Politehnica of Bucharest (Romania)

\section{Cosponsoring Institutions}

Ministry of Education and Research (Romania)

\section{* coherent. Coherent, Inc. (USA)}

FEKSPLA Ekspla (Lithuania) 
Downloaded From: https://www.spiedigitallibrary.org/conference-proceedings-of-spie on 26 Apr 2023

Terms of Use: https://www.spiedigitallibrary.org/terms-of-use 